\title{
Sugammadex as a reversal agent for neuromuscular block: an evidence-based review
}

This article was published in the following Dove Press journal:

Core Evidence

24 September 2013

Number of times this article has been viewed

\author{
Stefan Josef Schaller ${ }^{1,2}$ \\ Heidrun Fink' \\ 'Klinik für Anaesthesiologie, \\ Klinikum rechts der Isar, Technische \\ Universität München, Munich, \\ Germany; ${ }^{2}$ Department of Anesthesia, \\ Massachusetts General Hospital, \\ Boston, MA, USA
}

\begin{abstract}
Sugammadex is the first clinical representative of a new class of drugs called selective relaxant binding agents. It has revolutionized the way anesthesiologists think about drug reversal. Sugammadex selectively binds rocuronium or vecuronium, thereby reversing their neuromuscular blocking action. Due to its $1: 1$ binding of rocuronium or vecuronium, it is able to reverse any depth of neuromuscular block. So far, it has been approved for use in adult patients and for pediatric patients over 2 years. Since its approval in Europe, Japan, and Australia, further insight on its use in special patient populations and specific diseases have become available. Due to its pharmacodynamic profile, sugammadex, in combination with rocuronium, may have the potential to displace succinylcholine as the "gold standard" muscle relaxant for rapid sequence induction. The use of rocuronium or vecuronium, with the potential of reverse of their action with sugammadex, seems to be safe in patients with impaired neuromuscular transmission, ie, neuromuscular diseases, including myasthenia gravis. Data from long-term use of sugammadex is not yet available. Evidence suggesting an economic advantage of using sugammadex and justifying its relatively high cost for an anesthesia-related drug, is missing.
\end{abstract}

Keywords: reversal agent, cyclodextrin, PORC, SRBAs

\section{Core evidence clinical impact summary for sugammadex}

\begin{tabular}{|c|c|c|}
\hline Outcome measure & Evidence & Implications \\
\hline \multicolumn{3}{|l|}{ Patient-oriented evidence } \\
\hline $\begin{array}{l}\text { Reversal of neuromuscular block } \\
\text { by rocuronium or vecuronium }\end{array}$ & $\begin{array}{l}\text { Multiple randomized } \\
\text { clinical trials and } \\
\text { comparison to } \\
\text { antagonists }\end{array}$ & $\begin{array}{l}\text { Efficient reversor of } \\
\text { neuromuscular block and } \\
\text { superior to antagonists } \\
\text { regarding efficacy }\end{array}$ \\
\hline $\begin{array}{l}\text { Recommended doses for } \\
\text { profound, deep and moderate } \\
\text { neuromuscular block (immediate } \\
\text { reversal following } 1.2 \mathrm{mg} / \mathrm{kg} \\
\text { rocuronium, PTC I-2, TOF-C 2) }\end{array}$ & $\begin{array}{l}\text { Multiple randomized } \\
\text { clinical trials }\end{array}$ & $\begin{array}{l}\text { Recommended doses are } \\
\text { currently under postmarketing } \\
\text { surveillance (Phase IV) }\end{array}$ \\
\hline $\begin{array}{l}\text { Doses for shallow neuromuscular } \\
\text { block (TOF-C 4, TOF ratio } 0.5 \text { ) }\end{array}$ & $\begin{array}{l}\text { Single center } \\
\text { randomized trials }\end{array}$ & $\begin{array}{l}\text { Further studies (including } \\
\text { safety) pending }\end{array}$ \\
\hline \multicolumn{3}{|l|}{ Disease-oriented evidence } \\
\hline Renal disease & $\begin{array}{l}\text { Multicenter } \\
\text { parallel-group trial }\end{array}$ & $\begin{array}{l}2 \mathrm{mg} / \mathrm{kg} \text { sugammadex is } \\
\text { efficient in patients with renal } \\
\text { failure (creatinine clearance } \\
<30 \mathrm{~mL} / \mathrm{min} \text { ), however current } \\
\text { recommendations are to use } \\
\text { sugammadex only if creatinine } \\
\text { clearance }>30 \mathrm{~mL} / \mathrm{min}\end{array}$ \\
\hline
\end{tabular}




\begin{tabular}{|c|c|c|}
\hline $\begin{array}{l}\text { (Continued) } \\
\text { Outcome measure }\end{array}$ & Evidence & Implications \\
\hline Obese patients & $\begin{array}{l}\text { Single center } \\
\text { randomized trials } \\
\text { (heterogeneous } \\
\text { comparison groups) }\end{array}$ & $\begin{array}{l}\text { Doses according to ideal body } \\
\text { weight }+40 \% \text { instead of actual } \\
\text { body weight seems to be efficient } \\
\text { for reversal }\end{array}$ \\
\hline RSI & $\begin{array}{l}\text { Several randomized } \\
\text { clinical trials }\end{array}$ & $\begin{array}{l}\text { Combination of rocuronium and } \\
\text { sugammadex are an alternative to } \\
\text { succinylcholine for RSI }\end{array}$ \\
\hline Cesarian section & Several case series & $\begin{array}{l}\text { Rocuronium and sugammadex } \\
\text { might be a possible alternative to } \\
\text { succinylcholine for RSI for patients } \\
\text { undergoing a Cesarian section }\end{array}$ \\
\hline Electroconvulsive therapy & $\begin{array}{l}\text { Single center trials } \\
\text { (one randomized) }\end{array}$ & $\begin{array}{l}\text { Rocuronium followed by } \\
8 \mathrm{mg} / \mathrm{kg} \text { sugammadex after } \\
\text { electroconvulsive therapy is } \\
\text { completed seems to be an } \\
\text { alternative to succinylcholine }\end{array}$ \\
\hline $\begin{array}{l}\text { Myasthenia gravis and muscular } \\
\text { diseases }\end{array}$ & Case reports & $\begin{array}{l}\text { Sugammadex seems to be efficient } \\
\text { in such patients }\end{array}$ \\
\hline $\begin{array}{l}\text { Allergic/anaphylactic reaction } \\
\text { to rocuronium }\end{array}$ & $\begin{array}{l}\text { Case reports and } \\
\text { preclinical data }\end{array}$ & $\begin{array}{l}\text { Might be useful however standard } \\
\text { treatment of anaphylaxis has priority }\end{array}$ \\
\hline Economic evidence & $\begin{array}{l}\text { Limited data. } \\
\text { No prospective } \\
\text { randomized } \\
\text { economic trials }\end{array}$ & $\begin{array}{l}\text { Cost-effectiveness not proven. } \\
\text { Economic benefits highly } \\
\text { dependent on country, state or } \\
\text { hospital reimbursement system as } \\
\text { well as operation room logistics }\end{array}$ \\
\hline
\end{tabular}

\section{Introduction}

Muscle relaxants are routinely used worldwide as part of a modern concept of balanced anesthesia. They can be categorized as depolarizing (eg, succinylcholine) and nondepolarizing (steroid-based and benzylisoquinoline) muscle relaxants. Although nondepolarizing muscle relaxants have very few adverse effects (mostly allergic reactions) during anesthesia, a residual duration of action of muscle relaxants beyond the end of the operation, also referred to as postoperative residual curarization, is a well-known problem. Postoperative residual curarization can lead to respiratory insufficiency, ${ }^{1}$ impaired upper airway function, ${ }^{2}$ and increased risk of aspiration ${ }^{3}$ and consequently, of the risk of postoperative pulmonary complications. ${ }^{4}$

For decades, anesthesiologists have had three options for avoiding postoperative residual curarization and its complications:

1. They can opt not to use muscle relaxants at all. This, however, is not considered state of the art practice for several reasons: endotracheal intubation without using muscle relaxants increases the possibility of a difficult intubation, ${ }^{5}$ the risk of iatrogenic laryngeal trauma, and postoperative hoarseness. ${ }^{6}$
2. They can wait until the muscle relaxant is metabolized and neuromuscular transmission and muscle function has fully recovered spontaneously. However, aside from the different durations of action of the different muscle relaxants, there are also enormous interindividual differences in the speed that muscle relaxants are metabolized $^{7}$ and therefore, in how fast the patient recovers from paralysis.

3. They can antagonize the residual effect of muscle relaxants with a cholinesterase inhibitor, eg, neostigmine. This antagonism, however, has shortcomings:

a. Cholinesterase inhibitors work indirectly by increasing the acetylcholine concentration in the neuromuscular junction. This increases the chance of displacing the muscle relaxant from the acetylcholine receptor. Cholinesterase inhibitors can therefore only be used if the neuromuscular function has already recovered to a certain degree. In general, sufficient recovery to enable antagonism reversal is beyond a train of four (TOF) count of 4.

b. As cholinesterase inhibitors act, not only at the neuromuscular junction, but also, in the parasympathetic system, they have numerous unwanted side effects, eg, 
bradycardia. Thus, they are typically combined with a muscarinic antagonist (parasympatholytic drug), such as glycopyrrolate or atropine.

With the invention of sugammadex, a completely new possibility of neuromuscular block reversal was introduced to anesthesia practice. Sugammadex was approved for clinical use in Europe, in 2008 and in Japan, in 2010. Approval in the US by the Food and drug Administration (FDA) is pending.

This review will give (1) a short overview of the pharmaceutical properties of sugammadex and (2) focus on its clinical use. We searched in several databases (eg, PubMed and Medline) for peer-reviewed articles on sugammadex that were published before April 2013.

\section{Pharmacology Molecular characteristics}

Sugammadex is a modified $\gamma$-cyclodextrin specifically designed to encapsulate the muscle relaxant rocuronium. $\gamma$-cyclodextrins are cyclic oligosaccharide carbohydrates made of eight sugar molecules obtained from the degradation of starch. $\gamma$-cyclodextrin is a hydrophilic molecule with a lipophilic core that can encapsulate other lipophilic, preferably steroidal molecules. $\gamma$-cyclodextrins therefore have aqueous solubility, with the ability to bind lipophilic drugs. Although the eight identical hydroxyl side chains of sugammadex were specifically designed to bind rocuronium, the other steroidal muscle relaxants, vecuronium and pancuronium, are also bound by sugammadex, albeit with a much lower affinity (the equilibrium affinity constant value of rocuronium for sugammadex is $25,000,000 \mathrm{M}$, while for vecuronium, is only $10,000,000 \mathrm{M}$, meaning that the affinity is 2.5 times higher for rocuronium compared with vecuronium). ${ }^{8,9}$ One molecule of sugammadex is able to noncovalently bind one molecule of steroidal muscle relaxant. This binding is further increased by acid groups (COO-), which add an additional electrostatic bond interaction with the positively charged nitrogen of the muscle relaxant. No affinity exists to other muscle relaxants, like succinylcholine, mivacurium, atracurium, or cisatracurium.

\section{Pharmacokinetics}

When sugammadex is intravenously injected (central compartment), it immediately binds free intravascular rocuronium. This leads to a concentration gradient, which shifts rocuronium from the peripheral compartment (including the effect compartment, ie, the neuromuscular junction) towards the central compartment, where it is also encapsulated by sugammadex. This rapidly restores neuromuscular transmission and muscle function. A higher sugammadex dose is therefore more effective to lower the free rocuronium concentration in the plasma than a lower one. ${ }^{9}$

In a dose range of 0.1 to $16 \mathrm{mg} / \mathrm{kg}$, the pharmacokinetics of sugammadex show a linear, dose-dependent relationship. ${ }^{10}$ The elimination half-life of sugammadex is approximately $100-150$ minutes. It is not metabolized in the body and is nearly $100 \%$ cleared by the kidneys, with a clearance of about 75-120 $\mathrm{mL} / \mathrm{min}$, which equates to the normal glomerular filtration rate. Sugammadex is rapidly excreted from the body: a study using radioactive labeled sugammadex showed that in healthy volunteers, $70 \%$ of the dose was excreted in 6 hours and over $90 \%$ in 24 hours. ${ }^{11}$ Other data suggests an excretion of $59 \%$ to $80 \%$ in 24 hours. $^{9}$ It is of clinical relevance to note that in the presence of sugammadex, the hepatic biotransformation and final clearance, via biliary excretion, of rocuronium is changed to a completely different (liver-independent) renal pathway. As a result, special consideration must be given to patients with renal failure. Although sugammadex works as efficiently as in patients with normal renal function, ie, the mechanism of action of sugammadex is independent of renal perfusion, ${ }^{12,13}$ only $29 \%$ of the sugammadex-rocuronium molecules are cleared in 72 hours in end-stage renal failure. ${ }^{14}$ Although no cases of reoccurrence of neuromuscular block using $2 \mathrm{mg} / \mathrm{kg}$ sugammadex at a return of T2 ( 2 nd twitch of TOF stimulation) in renal failure patients have been reported, the use of sugammadex is not recommended in patients with low creatinine clearance $(<30 \mathrm{~mL} / \mathrm{min})$ or in need of dialysis, since the studies on this topic were not powered for safety. ${ }^{10,13}$ However, sugammadex can be dialyzed with the appropriate dialysis filter. ${ }^{15}$

\section{Clinical use/dosage}

Depending on the muscle relaxant used and the depth of the neuromuscular block at the time of reversal, different sugammadex doses are recommended. The doses should be able to accelerate the speed of recovery from the neuromuscular block to a TOF ratio of 0.9 in an average of 3 minutes. The different doses for rocuronium are summarized in Table 1.

There is no dose recommendation for the immediate reversal of a vecuronium-induced neuromuscular block. The sugammadex doses to reverse a deep (posttetanic count [PTC] of 1-2) or a moderate (TOF count $>2$ ) vecuronium-induced neuromuscular block are the same as for rocuronium; however, due to the lower affinity, the speed of recovery from the neuromuscular block is slightly slower (3.3 minutes after $4 \mathrm{mg} / \mathrm{kg}$ sugammadex, at a PTC of $1-2,{ }^{16}$ and $2.3 \mathrm{~min}$ after $2 \mathrm{mg} / \mathrm{kg}$, at a TOF count $>2^{17}$ ). 
Table I Sugammadex doses for an average reversal time of 3 minutes in a rocuronium- induced neuromuscular block

\begin{tabular}{llll}
\hline $\begin{array}{l}\text { Dose } \\
\text { sugammadex }\end{array}$ & Indication & $\begin{array}{l}\text { Mean recovery } \\
\text { time to TOF 0.9 }\end{array}$ & Remarks \\
\hline $16 \mathrm{mg} / \mathrm{kg}^{10,19}$ & Immediate reversal after $1.2 \mathrm{mg} / \mathrm{kg}$ rocuronium & 1.5 minutes & \\
$4 \mathrm{mg} / \mathrm{kg}^{10,16,20,21}$ & Routine reversal of deep neuromuscular block (PTC I-2) & 3 minutes & \\
$2 \mathrm{mg} / \mathrm{kg}^{10,17,22-25}$ & Routine reversal of moderate neuromuscular block (T2 appearance) & 2 minutes & Data from single-center RCT \\
$1 \mathrm{mg} / \mathrm{kg}^{26}$ & Reversal at reappearance of four twitches to TOF stimulation & 2 minutes & Data from single-center RCT \\
$0.22 \mathrm{mg} / \mathrm{kg}^{27}$ & Reversal at TOF 0.5 & 2 minutes & \\
\hline
\end{tabular}

Abbreviations: PTC, posttetanic count; RCT, randomized controlled trial; TOF, train of four count.

Doses of up to $96 \mathrm{mg} / \mathrm{kg}$ sugammadex have been tested and did not show any adverse effects in healthy adults. ${ }^{18}$

\section{Specific patient groups}

\section{Children}

Depending on their age, pediatric patients have shown a high variation in response to muscle relaxants as well as in recovery from neuromuscular block. ${ }^{28}$ Regarding the use of sugammadex in infants and children, little data is available due to the difficulty of obtaining informed consent in the pediatric study population. The recommended doses for adults seem to be equally efficient but have a faster onset time, with a very narrow range of individual response. ${ }^{22}$ So far, sugammadex has only been approved in children above 2 years of age, at a dose of $2 \mathrm{mg} / \mathrm{kg}$ for reversal of a moderate (TOF count $>2$ ) neuromuscular block. ${ }^{10}$

\section{Elderly}

Several studies have attempted to elucidate the changes in the efficacy and pharmacokinetics of sugammadex when used in elderly patients. In general, in patients above 65 years, recovery time has been prolonged, from $<2$ minutes to $<4$ minutes. This, however, is still considered to be sufficient. Therefore, no different dose recommendations have been issued. ${ }^{10,29,30}$ There is still discussion regarding whether or not the prolonged recovery time in elderly patients is a result of reduced cardiac output. ${ }^{31-33}$

\section{Obesity}

In obese patients, the dose of rocuronium is calculated according to ideal body weight, ${ }^{34-37}$ whereas it is recommended to dose sugammadex according to actual body weight. ${ }^{10}$ Interestingly, a dose of sugammadex calculated according to ideal body weight seems to be insufficient to reverse deep and moderate neuromuscular blocks in morbidly obese patients, ${ }^{38}$ while a dose calculated according to ideal body weight $+40 \%$ was shown to be effective in a clinical study $^{39}$ (mean reversal time $<2 \mathrm{~min}$ ). A final consensus on optimal sugammadex dosing in obese patients has not been reached so far. ${ }^{40-43}$ However, neuromuscular monitoring is recommended in all cases since a reoccurrence of the neuromuscular block is possible in obese patients receiving inadequate doses of sugammadex. ${ }^{44}$

\section{Pregnancy and breastfeeding women}

There is no clinical data available for the use of sugammadex in pregnant women. Animal studies showed no sign of direct or indirect negative side effects on the fetus, birth, or postnatal development. ${ }^{10}$

It is not known whether sugammadex is excreted into breast milk. Animal studies showed a certain degree of excretion. However, oral absorption of sugammadex is low, and no effects on the infant are expected. Sugammadex therefore is considered to be safe to use in breastfeeding women. ${ }^{10}$

\section{Specific indications}

\section{Sugammadex as acute therapeutic option in the event of an allergic reaction against rocuronium}

An allergic reaction to rocuronium is one of the most common causes of anaphylaxis in anesthesia..$^{45}$ The clinical appearance can range from a flush to cardiocirculatory arrest with the need for cardiopulmonary resuscitation. ${ }^{46}$ The exact incidence rate can only be estimated and varies from country to country. In France, where most case reports on rocuronium-induced allergy have originated, the incidence rate was estimated to be 1 in 6,500 anesthesia cases. Other estimates range from 1 in 1,000-2,000 to about 1 in $20,000 .{ }^{46} \mathrm{It}$ is more common in females (4:1), while history of allergies is not a risk factor. ${ }^{46}$ Since sugammadex binds rocuronium, it has been speculated that it can be used in an allergic reaction to rocuronium, to ameliorate the allergic cascade and subsequent symptoms. Several studies ${ }^{47-49}$ proved that with the encapsulation of rocuronium and building of the rocuronium-sugammadex complex, the epitope of the rocuronium molecule (which induces the allergic reaction) is hidden and does not further 
facilitate the allergic reaction. However, once the allergic cascade and mast cell activation has already been triggered, there are doubts that the withdrawal of rocuronium can stop the anaphylactic process. Although in an animal model, sugammadex reduced mast cell degranulation and number, ${ }^{50}$ sugammadex did not stop the allergic reaction in a cutaneous mode ${ }^{47}$ once it had been triggered by rocuronium. The same was true in a blood test study of three patients who were allergic to rocuronium. ${ }^{49}$

Clinically, only case reports on the treatment of a rocuronium-induced anaphylactic reaction with sugammadex are available. Six reports of female patients ${ }^{46,51-55}$ have been published that have shown an immediate and positive effect of sugammadex in a rocuronium-induced anaphylactic reaction. In contrast, there is a case report of another female patient ${ }^{56}$ who showed a similar timeline as was described in the other reports and a sudden improvement, without the use of sugammadex. It is speculated that the positive effects of sugammadex might be the non-immune-mediated effects on cardiac preload and afterload, secondary to the resumption of muscle tone. ${ }^{57}$ However, since most patients also received standard treatment for anaphylaxis, it is difficult to differentiate the individual effects of the different drugs. Since randomized studies are not possible for this scenario, further case reports and preclinical studies might be helpful to elucidate the possible effects and underlying mechanisms.

In summary, if sugammadex is to be considered as a therapeutic option for a severe allergic reaction to rocuronium, it should be given early and at a high dose, of $16 \mathrm{mg} / \mathrm{kg}^{51}$

\section{Rapid sequence induction (RSI) and "cannot intubate, cannot ventilate" situations}

Until now, succinylcholine has been the "gold standard" muscle relaxant for rapid sequence induction (RSI), due to its fast time of onset and short duration of action. However, succinylcholine has numerous contraindications and unwanted side effects, such as hyperkalemia, myalgia, and rhabdomyolysis. Rocuronium has been shown to be an alternative, with identical intubation conditions when used in appropriate doses $(1.2 \mathrm{mg} / \mathrm{kg}) .{ }^{58} \mathrm{~A}$ drawback to the use of a three- to fourfold effective dose (ED95) of rocuronium is a long duration of action, which could potentially endanger the patient in a "can't intubate, can't ventilate" situation. With the availability of sugammadex, the use of succinylcholine, with all its potential hazards, seems unnecessary. Several studies have shown that the rocuronium-sugammadex combination works as fast as succinylcholine regarding onset and recovery time. ${ }^{59-61}$ This has also been supported by a Cochrane review that showed that the rocuronium-sugammadex combination to be potentially safer than succinylcholine. ${ }^{62}$

However, before high-dose rocuronium is used for RSI with the idea of possible immediate reversal with sugammadex, it is of utmost importance that the anesthesia staff be adequately trained regarding the dose calculation and that there be storage of sugammadex within the operating area. Due to the high cost, in some institutions, the vials of sugammadex are often locked away or stored in a central area, making it unavailable for immediate use by every anesthesiologist when needed. This requirement is supported by a study that simulated a manikin-based "can't intubate, can't ventilate" situation and that showed that the appropriate dosage was difficult to calculate for anesthesia teams in an emergency scenario, leading to a delay in administration of sugammadex by, on average, 6.7 minutes. ${ }^{63}$ Further, in such a case, time is important since the recovery with rocuronium does not happen immediately but only with the administration of sugammadex, which requires an active decision followed by the actual action. ${ }^{64,65}$ In a situation with impending hypoxia due to the inability to oxygenate an anesthetized patient, time delays of even in the range of minutes can be crucial.

From a clinical point of view, it should always be remembered that avoiding a "can't intubate, can't ventilate" situation should be the primary focus of every anesthetist. Reversing a rocuronium-induced neuromuscular block with sugammadex only reverses the muscle paralysis. However, since the patient will have also received opioids and hypnotics, this does not necessarily mean that the "can't intubate, can't ventilate" situation is resolved. ${ }^{66-70}$ Thus, the most important task in avoiding a "can't intubate, can't ventilate" situation is the clinical evaluation of the upper airway. In case of an anticipated difficult intubation, other options than the possibility of sugammadex reversal, eg, Awake Fiberoptic Intubation should always be considered first and be available, and the anesthetist trained to perform this.

\section{Cesarean section}

When general anesthesia is given to patients receiving a Cesarean section, a rapid sequence technique is used, as pregnant women are not considered to be nil per os. As stated above, the use of $1.2 \mathrm{mg} / \mathrm{kg}$ rocuronium to facilitate endotracheal intubation is equally effective as $1 \mathrm{mg} / \mathrm{kg}$ succinylcholine. Rocuronium has not shown untoward effects on the neonates; ${ }^{71}$ if the neuromuscular block is reversed with sugammadex, this would occur after the baby is delivered, when the woman is no longer pregnant. However, 
so far, there have only been three case series of Cesarean sections ${ }^{72-74}$ available that detail the combination of rocuronium and sugammadex being used instead of succinylcholine. This regimen therefore seems a possible alternative that should be further investigated.

\section{Electroconvulsive therapy}

Electroconvulsive therapy (ECT) is another special indication for RSI. General anesthesia with complete muscle relaxation is mandatory for ECT; however, a treatment session only lasts several minutes. Succinylcholine is the preferred muscle relaxant for ECT for the same reasons as mentioned previously regarding succinylcholine and RSI. However, the combination of rocuronium and sugammadex is a promising new clinical alternative. A single-center study showed that the efficacy of rocuronium followed by $8 \mathrm{mg} / \mathrm{kg}$ sugammadex at the end of the ECT treatment was equally effective regarding recovery time compared with succinylcholine alone. ${ }^{33,75}$

\section{Myasthenia gravis and other specific myopathies}

The use of muscle relaxants in patients with muscular and neuromuscular diseases is challenging due to the altered sensitivity towards muscle relaxants, preexisting muscle weakness due to the myopathy itself, and also, the possible use of cholinesterase inhibitors as medication. Nonetheless, muscle relaxants should not be avoided in these patients if they require endotracheal intubation. The new strategy of muscle relaxant reversal using sugammadex seems to be a safe and reliable option in these patients. Six case reports in patients with myasthenia gravis document the successful use of sugammadex. ${ }^{76-80}$ For other rare muscular diseases, such as dermatomyositis, ${ }^{81}$ Duchenne muscular dystrophy, ${ }^{82}$ myotonic dystrophy, ${ }^{83-88}$ spinal muscular atrophy, ${ }^{88,89}$ and amyotrophic lateral sclerosis, ${ }^{90}$ case reports document the successful reversal of rocuronium with sugammadex, so that muscle function was quickly and reliably restored to the patients' preoperative state.

\section{Safety}

The most clinically relevant common side effects $(>2 \%)$ of sugammadex are due to the fast recovery of the muscle function during balanced anesthesia, which might unmask a too light anesthesia. In such cases, the patient might cough, move, grimace, or suckle on of the endotracheal tube. ${ }^{10,91}$

QT-Prolongation has been a concern since there have been reports of possible QT prolongation ${ }^{19,24}$ and one case of atrioventricular block after sugammadex. ${ }^{20}$ Several larger studies, however, have proven the safety of the drug, ${ }^{92-95}$ so that other factors during the administration of general anesthesia may have been a trigger in the reported cases.

As with all drugs, allergic reactions towards sugammadex are of concern. Cyclodextrins are ubiquitous molecules; therefore, an allergic predisposition is possible. This has been confirmed by several case reports of allergic reactions in patients who had received sugammadex for the first time. ${ }^{96-99}$ Reviews of both the published approval studies ${ }^{100}$ and of retrospective data from a single center in Japan over a period of 1 year ${ }^{97}$ show an incidence below $1 \%$.

Of clinical concern is the possible reoccurrence of neuromuscular block. In $2 \%$ of the patients in the Phase I-III trials, neuromuscular block deepened again after it had initially recovered. ${ }^{9,44}$ However, all patients with reoccurrence had not received the adequate dose of sugammadex, ie, they had received less than the recommended dose. In these patients, the redistribution of rocuronium from the peripheral compartment to the central (intravascular) compartment led to rocuronium plasma levels that were not adequately hepatically metabolized, nor encapsulated by free sugammadex, leading in turn, to a second redistribution into the effect compartment (neuromuscular junction). The reason that a small shift of rocuronium back into the effect compartment can lead to reoccurrence of neuromuscular block lies in the physiologic margin of safety of the neuromuscular transmission: A neuromuscular block only becomes evident when over $85 \%$ of acetylcholine receptors are occupied by the muscle relaxant; ${ }^{101}$ in other words, full muscle contraction, ie, a TOF ratio of $100 \%$ can be achieved even though $75 \%$ of acetylcholine receptors are still occupied. Therefore, a small recurring dose of rocuronium is able to occupy enough acetylcholine receptors to reestablish a certain degree of neuromuscular block. In an unlikely case of reoccurrence of neuromuscular block, the anesthesiologist cannot wait to see what the deepest level of block during this event will be. Consequently a high and safe dose should be given. There have not been studies looking at such a scenario to date; for purely safety reasons, the manufacturer recommends $4 \mathrm{mg} / \mathrm{kg}$ sugammadex..$^{10}$

\section{Contraindications}

An allergy to sugammadex is the only absolute contraindication. Additional diligence is necessary for patients with (1) bleeding disorders, (2) impaired renal function, and (3) patients using toremifene or fusidic acid. ${ }^{10}$

Phase I studies in volunteers using doses of $4 \mathrm{mg} / \mathrm{kg}$ up to $16 \mathrm{mg} / \mathrm{kg}$ showed that sugammadex led to prolonged activated 
partial thromboplastin time (aPTT) and prothrombin time (PT) or international normalized ratio (INR). These effects, however, were limited in time (below 30 minutes) and were not found to be clinical relevant. If the risk of bleeding is increased (either by hereditary factor deficiencies, coagulopathy, or use of medication), the possible additional anticoagulatory effects of sugammadex might become clinically relevant. Multicenter trials that will specifically look at bleeding complication after the use of sugammadex are currently under investigation. As of today, from a clinical perspective, the benefits of giving sugammadex have to be individually weighted against the possible risk of bleeding in such patients. ${ }^{10}$

Due to its renal elimination pathway, sugammadex should not be used in patients with highly impaired renal function, ie, creatinine clearance below $30 \mathrm{~mL} / \mathrm{min}$, or in patients requiring dialysis. ${ }^{10}$

Sugammadex is a cyclodextrin specifically designed to encapsulate rocuronium. Therefore drug interactions with other molecules seem to be rare. However, a potential change in efficacy could not be excluded for toremifene (estrogen receptor modulator) and fusidic acid (bacteriostatic antibiotic). ${ }^{102}$ Patients who receive these drugs might show a delayed recovery from neuromuscular block when receiving sugammadex. In addition, sugammadex might affect the efficacy of progesterone. Therefore, one bolus administration of sugammadex has to be considered as equivalent to one missed dose of hormonal contraceptives. It is suggested to use either a nonhormonal contraceptive method or to refer to the package leaflet of the contraceptive used and follow the directions for a missed dose. ${ }^{10}$

\section{Multiple doses of sugammadex}

If a patient has to undergo a reoperation after receiving sugammadex, three options to manage the neuromuscular block are available:

1. the use of succinylcholine;

2. the use of a benzylisoquinoline muscle relaxant (atracurium, cisatracurium, or mivacurium); or

3. a second use of rocuronium.

There is an ongoing discussion which is the best option. ${ }^{103,104}$ Some data suggest that 5 minutes after the administration for sugammadex, rocuronium can be used again but may have a slower onset and shorter duration time. Due to the high elimination from the body, this is improved 25 minutes after sugammadex has been administered. ${ }^{105}$ The recommended doses for a readministration after sugammadex can be found in Table 2. The onset of relaxation might be prolonged to up to 4 minutes and the duration of action reduced to 15 minutes. ${ }^{10}$ Neuromuscular monitoring is, in
Table 2 Dose recommendations for rocuronium after sugammadex use

\begin{tabular}{ll}
\hline $\begin{array}{l}\text { Wait time after } \\
\text { sugammadex }\end{array}$ & $\begin{array}{l}\text { Dose recommendation } \\
\text { for rocuronium }\end{array}$ \\
\hline 5 minutes & $1.2 \mathrm{mg} / \mathrm{kg}$ \\
4 hours & $0.6 \mathrm{mg} / \mathrm{kg}$ \\
\hline
\end{tabular}

Note: Data from Merck \& Co Inc. BRIDION: EPAR - Product Information Annex I: Summary of product characteristics. European Medicines Agency; London, UK. 2013.10

every case, essential to adequately assess the neuromuscular block of the individual patient.

\section{Economic aspects}

To exactly determine the anesthesia costs per hour or case is impossible due to huge differences in health care systems between countries, states, and even hospitals. However, for a 2-hour long uncomplicated surgery case, the following cost estimates for anesthesia provide at least a possibility of comparison for the reader: US\$956, for the US; ${ }^{106} € 722$, for Germany; ${ }^{107}$ and $¥ 61000$, for Japan. ${ }^{108}$ At a price of approximately $€ 100$ per $200 \mathrm{mg}$ vial, sugammadex is one of the most expensive drugs in anesthesia. Data regarding cost effectiveness for sugammadex is rare. Although the reversal time with sugammadex is clearly shorter than with neostigmine or spontaneous recovery, this does not necessarily mean that this gained time can be translated to an increase in patient cases in the operating room or a reduced hospital stay and cost reduction for the patient. ${ }^{109-111}$

Most reviews do not see an advantage in the overall costs of sugammadex..$^{100,109,112}$ Others even argue that sugammadex can hardly make economic sense in a typical clinical setting; ${ }^{113}$ to the contrary, it seems that sugammadex increases costs (8.22 euro/case calculated by Raft et al). ${ }^{114}$ From a simple hospital economic point of view, the cost efficacy of sugammadex also depends on the individual reimbursement system. In Japan, where additional costs can be charged to the patient, sugammadex is, despite these arguments, widely used; in Germany, where the health care system does not reimburse additional drug costs of that kind, the use of sugammadex is limited. Due to large differences in staffing and logistics between different countries and hospitals, a decision regarding the cost effectiveness of sugammadex will, at least at the moment, remain an individual decision.

\section{Summary}

Sugammadex is a potent, fast, and safe reversal agent for aminosteroid muscle relaxants and has the potential to change anesthesia practice. It has revolutionized the way anesthesiologists think about drug reversal and pharmaceutical 
dose-response control. It also has the potential to eliminate succinylcholine from anesthesia practice. However, the price of the drug and the missing evidence of cost efficacy has led to a limited use in clinical anesthesia so far.

\section{Disclosure}

Stefan Josef Schaller owns stock in Merck \& Co Inc. Heidrun Fink has received honoraria and travel grants from the following companies: MSD Sharp \& Dohme, Essex, Baxter, Care Fusion, GE Healthcare. The authors report no other conflicts of interest in this work.

\section{References}

1. Murphy GS, Szokol JW, Marymont JH, Greenberg SB, Avram MJ, Vender JS. Residual neuromuscular blockade and critical respiratory events in the postanesthesia care unit. Anesth Analg. 2008;107(1):130-137.

2. Eikermann M, Blobner M, Groeben H, et al. Postoperative upper airway obstruction after recovery of the train of four ratio of the adductor pollicis muscle from neuromuscular blockade. Anesth Analg. 2006; 102(3):937-942.

3. Sundman E, Witt H, Olsson R, Ekberg O, Kuylenstierna R, Eriksson LI. The incidence and mechanisms of pharyngeal and upper esophageal dysfunction in partially paralyzed humans: pharyngeal videoradiography and simultaneous manometry after atracurium. Anesthesiology. 2000;92(4):977-984.

4. Berg H, Roed J, Viby-Mogensen J, et al. Residual neuromuscular block is a risk factor for postoperative pulmonary complications. A prospective, randomised, and blinded study of postoperative pulmonary complications after atracurium, vecuronium and pancuronium. Acta Anaesthesiol Scand. 1997;41(9):1095-1103.

5. Combes X, Andriamifidy L, Dufresne E, et al. Comparison of two induction regimens using or not using muscle relaxant: impact on postoperative upper airway discomfort. Br J Anaesth. 2007;99(2):276-281.

6. Mencke T, Echternach M, Kleinschmidt S, et al. Laryngeal morbidity and quality of tracheal intubation: a randomized controlled trial. Anesthesiology. 2003;98(5):1049-1056.

7. Debaene B, Plaud B, Dilly MP, Donati F. Residual paralysis in the PACU after a single intubating dose of nondepolarizing muscle relaxant with an intermediate duration of action. Anesthesiology. 2003;98(5): 1042-1048.

8. Bom A, Hope F, Rutherford S, Thomson K. Preclinical pharmacology of sugammadex. J Crit Care. 2009;24(1):29-35.

9. Akha AS, Rosa J, Jahr JS, Li A, Kiai K. Sugammadex: cyclodextrins, development of selective binding agents, pharmacology, clinical development, and future directions. Anesthesiol Clin. 2010;28(4):691-708.

10. Merck \& Co Inc. BRIDION: EPAR - Product Information Annex I: Summary of product characteristics. European Medicines Agency; London, UK. 2013. Available from: http://www.ema.europa.eu/docs/en_GB/ document_library/EPAR_-_Product_Information/human/000885/ WC500052310.pdf. Accessed June 13, 2013.

11. Peeters P, Passier P, Smeets J, et al. Sugammadex is cleared rapidly and primarily unchanged via renal excretion. Biopharm Drug Dispos. 2011;32(3):159-167.

12. Staals LM, de Boer HD, van Egmond J, et al. Reversal of rocuroniuminduced neuromuscular block by sugammadex is independent of renal perfusion in anesthetized cats. J Anesth. 2011;25(2):241-246.

13. Staals LM, Snoeck MM, Driessen JJ, Flockton EA, Heeringa M, Hunter JM. Multicentre, parallel-group, comparative trial evaluating the efficacy and safety of sugammadex in patients with end-stage renal failure or normal renal function. Br J Anaesth. 2008;101(4):492-497.

14. Staals LM, Snoeck MM, Driessen JJ, et al. Reduced clearance of rocuronium and sugammadex in patients with severe to end-stage renal failure: a pharmacokinetic study. Br J Anaesth. 2010;104(1):31-39.
15. Cammu G, Van Vlem B, van den Heuvel M, et al. Dialysability of sugammadex and its complex with rocuronium in intensive care patients with severe renal impairment. Br J Anaesth. 2012;109(3):382-390.

16. Duvaldestin P, Kuizenga K, Saldien V, et al. A randomized, dose-response study of sugammadex given for the reversal of deep rocuronium- or vecuronium-induced neuromuscular blockade under sevoflurane anesthesia. Anesth Analg. 2010;110(1):74-82.

17. Suy K, Morias K, Cammu G, et al. Effective reversal of moderate rocuronium- or vecuronium-induced neuromuscular block with sugammadex, a selective relaxant binding agent. Anesthesiology. 2007;106(2):283-288.

18. Peeters PA, van den Heuvel MW, van Heumen E, et al. Safety, tolerability and pharmacokinetics of sugammadex using single high doses (up to $96 \mathrm{mg} / \mathrm{kg}$ ) in healthy adult subjects: a randomized, double-blind, crossover, placebo-controlled, single-centre study. Clin Drug Investig. 2010;30(12):867-874.

19. de Boer HD, Driessen JJ, Marcus MA, Kerkkamp H, Heeringa M, Klimek M. Reversal of rocuronium-induced $(1.2 \mathrm{mg} / \mathrm{kg})$ profound neuromuscular block by sugammadex: a multicenter, dose-finding and safety study. Anesthesiology. 2007;107(2):239-244.

20. Groudine SB, Soto R, Lien C, Drover D, Roberts K. A randomized, dose-finding, phase II study of the selective relaxant binding drug, Sugammadex, capable of safely reversing profound rocuronium-induced neuromuscular block. Anesth Analg. 2007;104(3):555-562.

21. Jones RK, Caldwell JE, Brull SJ, Soto RG. Reversal of profound rocuronium-induced blockade with sugammadex: a randomized comparison with neostigmine. Anesthesiology. 2008;109(5): 816-824.

22. Plaud B, Meretoja O, Hofmockel R, et al. Reversal of rocuroniuminduced neuromuscular blockade with sugammadex in pediatric and adult surgical patients. Anesthesiology. 2009;110(2):284-294.

23. Flockton EA, Mastronardi P, Hunter JM, et al. Reversal of rocuroniuminduced neuromuscular block with sugammadex is faster than reversal of cisatracurium-induced block with neostigmine. $\mathrm{Br} J$ Anaesth. 2008;100(5):622-630.

24. Vanacker BF, Vermeyen KM, Struys MM, et al. Reversal of rocuronium-induced neuromuscular block with the novel drug sugammadex is equally effective under maintenance anesthesia with propofol or sevoflurane. Anesth Analg. 2007;104(3):563-568.

25. Sorgenfrei IF, Norrild K, Larsen PB, et al. Reversal of rocuroniuminduced neuromuscular block by the selective relaxant binding agent sugammadex: a dose-finding and safety study. Anesthesiology. 2006;104(4):667-674.

26. Pongrácz A, Szatmári S, Nemes R, Fülesdi B, Tassonyi E. Reversal of Neuromuscular Blockade with Sugammadex at the Reappearance of Four Twitches to Train-of-four Stimulation. Anesthesiology. 2013;119(1):36-42.

27. Schaller SJ, Fink H, Ulm K, Blobner M. Sugammadex and neostigmine dose-finding study for reversal of shallow residual neuromuscular block. Anesthesiology. 2010;113(5):1054-1060.

28. Meretoja OA. Neuromuscular block and current treatment strategies for its reversal in children. Paediatr Anaesth. 2010;20(7):591-604.

29. McDonagh DL, Benedict PE, Kovac AL, et al. Efficacy, safety, and pharmacokinetics of sugammadex for the reversal of rocuroniuminduced neuromuscular blockade in elderly patients. Anesthesiology. 2011;114(2):318-329.

30. Suzuki T, Kitajima O, Ueda K, Kondo Y, Kato J, Ogawa S. Reversibility of rocuronium-induced profound neuromuscular block with sugammadex in younger and older patients. Br J Anaesth. 2011;106(6): 823-826.

31. Yoshida F, Suzuki T, Kashiwai A, Furuya T, Konishi J, Ogawa S. Correlation between cardiac output and reversibility of rocuroniuminduced moderate neuromuscular block with sugammadex. Acta Anaesthesiol Scand. 2012;56(1):83-87.

32. Cammu G, Coart D, De Graeve K, Beelen R. Reversal of rocuroniuminduced neuromuscular block with sugammadex in heart failure patients: a prospective observational study. Acta Anaesthesiol Belg. 2012;63(2):69-73. 
33. Kadoi Y, Nishida A, Saito S. Recovery time after sugammadex reversal of rocuronium-induced muscle relaxation for electroconvulsive therapy is independent of cardiac output in both young and elderly patients. J ECT. 2013;29(1):33-36.

34. Meyhoff CS, Lund J, Jenstrup MT, et al. Should dosing of rocuronium in obese patients be based on ideal or corrected body weight? Anesth Analg. 2009;109(3):787-792.

35. Leykin Y, Pellis T, Lucca M, Lomangino G, Marzano B, Gullo A. The pharmacodynamic effects of rocuronium when dosed according to real body weight or ideal body weight in morbidly obese patients. Anesth Analg. 2004;99(4):1086-1089

36. de Baerdemaeker LEC, Mortier EP, Struys MMRF. Pharmacokinetics in obese patients. CEACCP. 2004;4(5):152-155.

37. Gaszynski TM, Szewczyk T. Rocuronium for rapid sequence induction in morbidly obese patients: a prospective study for evaluation of intubation conditions after administration $1.2 \mathrm{mg} \mathrm{kg}^{-1}$ ideal body weight of rocuronium. Eur J Anaesthesiol. 2011;28(8):609-610.

38. Llauradó S, Sabaté A, Ferreres E, Camprubí I, Cabrera A. Sugammadex ideal body weight dose adjusted by level of neuromuscular blockade in laparoscopic bariatric surgery. Anesthesiology. 2012;117(1):93-98.

39. Van Lancker P, Dillemans B, Bogaert T, Mulier JP, De Kock M, Haspeslagh M. Ideal versus corrected body weight for dosage of sugammadex in morbidly obese patients. Anaesthesia. 2011;66(8) 721-725.

40. Schmartz D, Guerci P, Fuchs-Buder T. Sugammadex dosing in bariatric patients. Anesthesiology. 2013;118(3):754.

41. Carron M, Parotto E, Ori C. The use of sugammadex in obese patients Can J Anaesth. 2012;59(3):321-322.

42. Carron M, Freo U, Parotto E, Ori C. The correct dosing regimen for sugammadex in morbidly obese patients. Anaesthesia. 2012;67(3): 298-299.

43. Sabaté A, Llauradó S. Ideal versus corrected body weight for dosage of sugammadex in morbidly obese patients. Anaesthesia. 2012;67(6):682; author reply 682-683.

44. Le Corre F, Nejmeddine S, Fatahine C, Tayar C, Marty J, Plaud B. Recurarization after sugammadex reversal in an obese patient. Can J Anaesth. 2011;58(10):944-947.

45. Dewachter P, Mouton-Faivre C, Emala CW. Anaphylaxis and anesthesia: controversies and new insights. Anesthesiology. 2009;111(5): 1141-1150.

46. Baldo BA, McDonnell NJ, Pham NH. Drug-specific cyclodextrins with emphasis on sugammadex, the neuromuscular blocker rocuronium and perioperative anaphylaxis: implications for drug allergy. Clin Exp Allergy. 2011;41(12):1663-1678.

47. Clarke RC, Sadleir PH, Platt PR. The role of sugammadex in the development and modification of an allergic response to rocuronium: evidence from a cutaneous model. Anaesthesia. 2012;67(3): 266-273.

48. Kawano T, Yokoyama M. Can sugammadex encapsulation eliminate the antigenic activity of aminosteroidal neuromuscular blocking agent? J Anesth. 2011;25(6):953-954.

49. Leysen J, Bridts CH, De Clerck LS, Ebo DG. Rocuronium-induced anaphylaxis is probably not mitigated by sugammadex: evidence from an in vitro experiment. Anaesthesia. 2011;66(6):526-527.

50. Tomak Y, Yilmaz A, Bostan H, et al. Effects of sugammadex and rocuronium mast cell number and degranulation in rat liver. Anaesthesia. 2012;67(10):1101-1104.

51. Barthel F, Stojeba N, Lyons G, Biermann C, Diemunsch P. Sugammadex in rocuronium anaphylaxis: dose matters. Br J Anaesth. 2012;109(4):646-647.

52. Motamed C, Baguenard P, Bourgain JL. Possible mitigation of rocuronium-induced anaphylaxis after administration of sugammadex. J Anaesthesiol Clin Pharmacol. 2012;28(1):127-128.

53. Kawano T, Tamura T, Hamaguchi M, Yatabe T, Yamashita K, Yokoyama M. Successful management of rocuronium-induced anaphylactic reactions with sugammadex: a case report. $J$ Clin Anesth. 2012;24(1):62-64
54. Funnell AE, Griffiths J, Hodzovic I. A further case of rocuroniuminduced anaphylaxis treated with sugammadex. $\mathrm{Br} J$ Anaesth. 2011;107(2):275-276.

55. McDonnell NJ, Pavy TJ, Green LK, Platt PR. Sugammadex in the management of rocuronium-induced anaphylaxis. Br J Anaesth. 2011;106(2):199-201.

56. White PF, Tufanogullari B, Sacan O, et al. The effect of residual neuromuscular blockade on the speed of reversal with sugammadex. Anesth Analg. 2009;108(3):846-851.

57. Clarke R, Sadleir P, Platt P. A reply. Anaesthesia. 2012;67(10):1175.

58. Perry JJ, Lee JS, Sillberg VA, Wells GA. Rocuronium versus succinylcholine for rapid sequence induction intubation [review]. Cochrane Database Syst Rev. 2008;2:CD002788.

59. McCahon R. Role of sugammadex in rapid sequence induction and intubation. Br J Anaesth. 2012;109(1):123; author reply 123-124.

60. Lee C, Jahr JS, Candiotti KA, Warriner B, Zornow MH, Naguib M. Reversal of profound neuromuscular block by sugammadex administered three minutes after rocuronium: a comparison with spontaneous recovery from succinylcholine. Anesthesiology. 2009;110(5): $1020-1025$

61. Sørensen MK, Bretlau C, Gätke MR, Sørensen AM, Rasmussen LS. Rapid sequence induction and intubation with rocuronium-sugammadex compared with succinylcholine: a randomized trial. Br J Anaesth. 2012;108(4):682-689.

62. Abrishami A, Ho J, Wong J, Yin L, Chung F. Sugammadex, a selective reversal medication for preventing postoperative residual neuromuscular blockade [review]. Cochrane Database Syst Rev. 2009;4:CD007362.

63. Bisschops MM, Holleman C, Huitink JM. Can sugammadex save a patient in a simulated 'cannot intubate, cannot ventilate' situation? Anaesthesia. 2010;65(9):936-941.

64. Ackerman AG, Russ S, Puttick N, Kessell G. Availability and storage of sugammadex for emergency use. Anaesthesia. 2011;66(2):139-140.

65. Dada A, Dunsire F. Can sugammadex save a patient in a simulated 'cannot intubate, cannot ventilate' scenario? Anaesthesia. 2011;66(2): 141-142.

66. Ezri T, Evron S. Sugammadex and the cannot intubate/cannot ventilate scenario in patients with predicted difficult airway (1). Letter 1. $\mathrm{Br} J$ Anaesth. 2012;109(3):459; author reply 459-462.

67. Telgarsky B, Stacey M. Sugammadex and the cannot intubate/cannot ventilate scenario in patients with predicted difficult airway (1). Letter 2. Br J Anaesth. 2012;109(3):459-460; author reply 461.

68. Watson SJ, Jefferson P, Ball DR. Sugammadex and the cannot intubate/ cannot ventilate scenario in patients with predicted difficult airway (1) Letter 3. Br J Anaesth. 2012;109(3):460-461; author reply 461

69. Kyle BC, Gaylard D, Riley RH. A persistent 'can't intubate, can't oxygenate' crisis despite rocuronium reversal with sugammadex. Anaesth Intensive Care. 2012;40(2):344-346.

70. Curtis R, Lomax S, Patel B. Use of sugammadex in a 'can't intubate, can't ventilate' situation. Br J Anaesth. 2012;108(4):612-614.

71. Abouleish E, Abboud T, Lechevalier T, Zhu J, Chalian A, Alford K. Rocuronium (Org 9426) for caesarean section. Br J Anaesth. 1994; 73(3):336-341.

72. Nauheimer D, Kollath C, Geldner G. Modified rapid sequence induction for Caesarian sections: case series on the use of rocuronium and sugammadex. Anaesthesist. 2012;61(8):691-695. German.

73. Pühringer FK, Kristen P, Rex C. Sugammadex reversal of rocuroniuminduced neuromuscular block in Caesarean section patients: a series of seven cases. Br J Anaesth. 2010;105(5):657-660.

74. Williamson RM, Mallaiah S, Barclay P. Rocuronium and sugammadex for rapid sequence induction of obstetric general anaesthesia. Acta Anaesthesiol Scand. 2011;55(6):694-699.

75. Kadoi Y, Hoshi H, Nishida A, Saito S. Comparison of recovery times from rocuronium-induced muscle relaxation after reversal with three different doses of sugammadex and succinylcholine during electroconvulsive therapy. J Anesth. 2011;25(6):855-859.

76. Unterbuchner C, Fink H, Blobner M. The use of sugammadex in a patient with myasthenia gravis. Anaesthesia. 2010;65(3):302-305. 
77. Petrun AM, Mekis D, Kamenik M. Successful use of rocuronium and sugammadex in a patient with myasthenia. Eur J Anaesthesiol. 2010;27(10):917-918

78. de Boer HD, van Egmond J, Driessen JJ, Booij LH. Sugammadex in patients with myasthenia gravis. Anaesthesia. 2010;65(6):653.

79. Rudzka-Nowak A, Piechota M. Anaesthetic management of a patient with myasthenia gravis for abdominal surgery using sugammadex. Arch Med Sci. 2011;7(2):361-364.

80. Garcia V, Diemunsch P, Boet S. Use of rocuronium and sugammadex for caesarean delivery in a patient with myasthenia gravis. Int J Obstet Anesth. 2012;21(3):286-287.

81. Suzuki T, Nameki K, Shimizu H, Shimizu Y, Nakamura R, Ogawa S. Efficacy of rocuronium and sugammadex in a patient with dermatomyositis. Br J Anaesth. 2012;108(4):703.

82. de Boer HD, van Esmond J, Booij LH, Driessen JJ. Reversal of rocuronium-induced profound neuromuscular block by sugammadex in Duchenne muscular dystrophy. Paediatr Anaesth. 2009;19(12): 1226-1228.

83. Baumgartner P. Rocuronium and sugammadex in myotonic dystrophy. Anaesth Intensive Care. 2010;38(5):959-960.

84. Kashiwai A, Suzuki T, Ogawa S. Sensitivity to rocuronium-induced neuromuscular block and reversibility with sugammadex in a patient with myotonic dystrophy. Case Rep Anesthesiol. 2012;2012:107952.

85. Matsuki Y, Hirose M, Tabata M, Nobukawa Y, Shigemi K. The use of sugammadex in a patient with myotonic dystrophy. Eur J Anaesthesiol. 2011;28(2):145-146.

86. Petrovski J. The use of sugammadex to reverse rocuronium in a patient with myotonic dystrophy. Anaesth Intensive Care. 2011;39(3): 505-506.

87. Stewart PA, Phillips S, de Boer HD. Residual neuromuscular blockade in myotonic dystrophy: lessons unlearned and sugammadex. Anaesth Intensive Care. 2011;39(4):756-757; author reply 757.

88. Stewart PA, Phillips S, De Boer HD. Sugammadex reversal of rocuronium-induced neuromuscular blockade in two types of neuromuscular disorders: Myotonic dystrophy and spinal muscular atrophy. Rev Esp Anestesiol Reanim. 2013;60(4):226-229.

89. Vilela H, Santos J, Colaço J, Oliveira E, Canas-da-Silva P. Reversal of neuromuscular blockade with sugammadex in a patient with spinal muscular atrophy type III (Kugelberg-Welander syndrome). J Anesth. 2012;26(2):306-307.

90. Kelsaka E, Karakaya D, Zengin EC. Use of sugammadex in a patient with amyotrophic lateral sclerosis. Med Princ Pract. 2013;22(3):304-306.

91. Sparr HJ, Vermeyen KM, Beaufort AM, et al. Early reversal of profound rocuronium-induced neuromuscular blockade by sugammadex in a randomized multicenter study: efficacy, safety, and pharmacokinetics. Anesthesiology. 2007;106(5):935-943.

92. Cammu G, De Kam PJ, Demeyer I, et al. Safety and tolerability of single intravenous doses of sugammadex administered simultaneously with rocuronium or vecuronium in healthy volunteers. Br J Anaesth. 2008;100(3):373-379.

93. Dahl V, Pendeville PE, Hollmann MW, Heier T, Abels EA, Blobner M. Safety and efficacy of sugammadex for the reversal of rocuroniuminduced neuromuscular blockade in cardiac patients undergoing noncardiac surgery. Eur J Anaesthesiol. 2009;26(10):874-884.

94. de Kam PJ, van Kuijk J, Prohn M, Thomsen T, Peeters P. Effects of sugammadex doses up to $32 \mathrm{mg} / \mathrm{kg}$ alone or in combination with rocuronium or vecuronium on QTc prolongation: a thorough QTc study. Clin Drug Investig. 2010;30(9):599-611.

95. de Kam PJ, van Kuijk J, Smeets J, Thomsen T, Peeters P. Sugammadex is not associated with QT/QTc prolongation: methodology aspects of an intravenous moxifloxacin-controlled thorough QT study. Int J Clin Pharmacol Ther. 2012;50(8):595-604.

96. Soria A, Motamed C, Gaouar H, Chemam S, Amsler E, Francès C. Severe reaction following sugammadex injection: hypersensitivity? J Investig Allergol Clin Immunol. 2012;22(5):382.
97. Godai K, Hasegawa-Moriyama M, Kuniyoshi T, et al. Three cases of suspected sugammadex-induced hypersensitivity reactions. $\mathrm{Br} J$ Anaesth. 2012;109(2):216-218.

98. Kokki M, Ali M, Turunen M, Kokki H. Suspected unexpected adverse effect of sugammadex: hypotension. Eur J Clin Pharmacol. 2012;68(5):899-900.

99. Menéndez-Ozcoidi L, Ortiz-Gómez JR, Olaguibel-Ribero JM, Salvador-Bravo MJ. Allergy to low dose sugammadex. Anaesthesia. 2011;66(3):217-219.

100. Chambers D, Paulden M, Paton F, et al. Sugammadex for reversal of neuromuscular block after rapid sequence intubation: a systematic review and economic assessment. Br J Anaesth. 2010;105(5):568-575.

101. Lingle CJ, Steinbach JH. Neuromuscular blocking agents. Int Anesthesiol Clin. 1988;26(4):288-301.

102. Zwiers A, van den Heuvel M, Smeets J, Rutherford S. Assessment of the potential for displacement interactions with sugammadex: a pharmacokinetic-pharmacodynamic modelling approach. Clin Drug Investig. 2011;31(2):101-111.

103. Fabregat-López J, Veiga-Ruiz G, Dominguez-Serrano N, García-Martinez MR. Re-establishment of neuromuscular block by rocuronium after sugammadex administration. Can J Anaesth. 2011;58(7):658-659.

104. Harris P. Unexpected failure of rocuronium-mediated neuromuscular blockade. Anaesthesia. 2011;66(6):525; author reply 525-525; author reply 526.

105. Cammu G, de Kam PJ, De Graeve K, et al. Repeat dosing of rocuronium $1.2 \mathrm{mg} \mathrm{kg}^{-1}$ after reversal of neuromuscular block by sugammadex $4.0 \mathrm{mg} \mathrm{kg}^{-1}$ in anaesthetized healthy volunteers: a modelling-based pilot study. Br J Anaesth. 2010;105(4):487-492.

106. healthcarebluebook.com [homepage on the Internet]. Cholecystectomy (laparoscopic). Health Care Blue Book; 2013. Available from: http://www.healthcarebluebook.com/page_Results. aspx?id=74\&dataset=MD. Accessed June 10, 2013.

107. Berry M, Martin J, Geldner G, et al. Analyse der IST-kosten Anäshtesie in deutschen krankenhäusern. [Analysis of actual costs of anesthesia in German Hospitals] Klinikum Ludwigsburg. 2007;48(3):140-146. German.

108. Ministry of Health, Labour and Welfare (Japan). Fee Regulation for General Anesthesia. Tokyo: Ministry of Health, Labour and Welfare (Japan); 2013. Available from: http://www.mhlw.go.jp/ stf/shingi/2r9852000001va4h-att/2r9852000001vak5.pdf. Accessed June 10, 2013. Japanese.

109. Paton F, Paulden M, Chambers D, et al. Sugammadex compared with neostigmine/glycopyrrolate for routine reversal of neuromuscular block: a systematic review and economic evaluation. Br J Anaesth. 2010;105(5):558-567.

110. Cammu GV, Smet V, De Jongh K, Vandeput D. A prospective, observational study comparing postoperative residual curarisation and early adverse respiratory events in patients reversed with neostigmine or sugammadex or after apparent spontaneous recovery. Anaesth Intensive Care. 2012;40(6):999-1006.

111. Ledowski T, Hillyard S, Kozman A, et al. Unrestricted access to sugammadex: impact on neuromuscular blocking agent choice, reversal practice and associated healthcare costs. Anaesth Intensive Care. 2012;40(2):340-343.

112. Chambers D, Paulden M, Paton F, et al. Sugammadex for the reversal of muscle relaxation in general anaesthesia: a systematic review and economic assessment. Health Technol Assess. 2010;14(39):1-211.

113. Kopman AF. Neostigmine versus sugammadex: which, when, and how much? Anesthesiology. 2010;113(5):1010-1011.

114. Raft J, Chenot ED, Longrois D, Meistelman C. Analysis of neuromuscular blocking drugs and sugammadex expenses, one year after its introduction into routine clinical practice. Ann Fr Anesth Reanim. 2011;30(10):758-759. French. 


\section{Core Evidence}

\section{Publish your work in this journal}

Core Evidence is an international, peer-reviewed open-access journal evaluating the evidence underlying the potential place in therapy of drugs throughout their development lifecycle from preclinical to postlaunch. The focus of each review is to evaluate the case for a new drug or class in outcome terms in specific indications and patient groups.

Submit your manuscript here: http://www.dovepress.com/core-evidence-journal
The manuscript management system is completely online and includes a very quick and fair peer-review system, which is all easy to use. Visit http://www.dovepress.com/testimonials.php to read real quotes from published authors. 